\title{
Research on Optimization Strategy of Cost-Sharing Mechanism of Human Capital Investment
}

\author{
Jing LIU \\ Business School of Jiangxi Normal University, \\ Nanchang, China \\ jxsdjh@vip.sina.com
}

\author{
Wen-fang FANG \\ Business School of Jiangxi Normal University, \\ Nanchang, China \\ 1303918988@qq.com
}

\begin{abstract}
The human resources investment in China has entered the popular stage, and the characteristics of the quasipublic products of human resources determine the cost sharing as a necessity. Although human resource cost sharing policy is quite reasonable, there are drawbacks that will affect the achievement of equal opportunity goals to a certain extent. This paper first describes the theoretical basis of research, and then the cost sharing of human capital investment is analyzed. Finally, countermeasures and Suggestions are put forward to promote the implementation of education.
\end{abstract}

Keywords-Human capital investment; cost sharing; equality of opportunity; strategy

\section{INTRODUCTION}

For developing countries such as China, human capital investment is shared by the beneficiaries and it is an inevitable choice to promote the reform of human capital investment system and promote the healthy development of education[1]. However, the current personal cost level of human capital investment has become a heavy burden for low-income families. In the absence of adequate supporting measures, high tuition fees are likely to be a barrier for many families to accept education, causing the inequality of the education opportunity and education results. On the whole, our country should be able to solve the education fairness issue through government, society, schools on the basis of the reasonable cost of education.

\section{The TheOREtical BAsis Of Human CAPITAL InVESTMENT}

This paper, based on the theory of human capital investment theory, public goods theory, public choice theory, human resources cost sharing theory and education equity theory, has important theoretical research value and significance.

\section{A. Human capital theory}

Human resource is the most important resource of all resources, human capital theory is the core problem of economics[2]. In economic growth, the role of human capital is greater than that of physical capital. The core of human capital is to improve population quality, and education investment is a major part of human investment. The reproduction of human capital should not be regarded as merely consumption, but as an investment, the economic benefit of this investment is much greater than that of material investment. Education is the most basic means of raising human capital, so it can also be regarded as the investment problem of education.

\section{B. Theory of public goods}

Commodities are divided into public and private parts by public sector economics. Public goods are exclusive and competitive goods that do not have consumption, and their interests are shared by the society. A private commodity whose interests are solely enjoyed by its consumers. The human resource is a commodity that is somewhere in between, which is characterized by public goods and private goods, called quasi-public goods. On the one hand, after the developers acquire knowledge and skills, they can obtain relatively high income and have the nature of private goods in the future work. On the other hand, there are a number of human resource development interests that are overflowed by the developers and have the nature of public goods.

\section{Public choice theory}

Public option means what kind of public goods people provide, how to provide and distribute public goods, and how to set up matching rules to act and process. Therefore, the public option faces efficiency and fairness. Efficiency is focused on the allocation efficiency of human capital investment to reduce idle resources and waste, making the allocation of resources more in the public interest. The focus on social justice focuses on the equality of opportunities for education. The government should make the fairest choice to ensure equal learning opportunities for students of different classes.

\section{Cost sharing theory}

The development of human resources requires a great deal of investment. Human resources is a quasi-public commodity whose production and supply costs should not be fully borne by the state, and it also should not be solely paid by the recipients. It should be shared by the government, enterprises, families and individuals. Through cost sharing, not only can better compensation cost of human resource in the supply of goods and services, ensuring the middle-income and poor families to accept education equality of opportunity, also can improve the efficiency of human resource supply. 


\section{E. Education equity theory}

One of the most important aspects of social justice is the fairness of education. Education fairness is an extension and embodiment of social justice and is an important way to realize social fairness. The principle of equal opportunity for education means: students from low-income families and disadvantaged backgrounds which regardless of gender, race and territory, it is necessary to get proper compensation from education system to enjoy equal rights to education.

\section{Human CAPITAL InVESTMENT CoSt SHARE EXISTING PROBLEM}

China's current human resources cannot meet the needs of the broad masses of people, so there is still a question of fairness of education in our country.

\section{A. Family difference level}

In the current society, the differences between different families are essentially caused by differences in social class[3]. Families of different classes have different economic, wealth, resources and status, and the education opportunities are not equal. Families of cadres, families of intellectuals and highincome families can let their children enter key schools and noble schools to receive high-quality education resources and they can also make up for the flaws in scores by paying the money, and get the chance to enroll. However, some students and families have to give up the opportunity to study because of economic poverty. The problem of family differences will inevitably affect the fairness of education.

\section{B. Regional economic development is unbalanced}

The unbalanced development of regional economy mainly refers to the gap between the eastern and western regions[4]. There are fewer colleges and universities in western China, and a large number of high-quality schools are concentrated in the developed areas of the east coast. The economic development of the eastern part of our country has a strong economic strength, so it can increase its investment in education. The economic base of the underdeveloped western regions is weak and it is difficult to invest large amounts of money to invest in education. People living in less developed areas have lower incomes and pay for their children to receive education and Households' spending on education is far greater than those in economically developed regions.

\section{The difference of urban-rural dual structure}

The urban-rural dual structure in China is a city-centric value orientation system. There are obvious differences in goals, status and security with urban and rural education. The distribution of human capital investment in urban and rural areas is obviously unfair. The rural public infrastructure and teachers are poor, and the proportion of students who can achieve the grades of various key schools is even lower. When allocating human capital investment, China has certain urban orientations which have relatively high levels of investment in cities with high levels of economic development. The capital expenditure of education in urban population is higher than that of the rural population, so the urban population is higher than the rural population. That makes it unfair for urban and rural students to share education resources, leaving some of the best students in rural areas with no chance to go to school. In part, it has reduced the chances of rural students going to university.

\section{School diversity}

The policy of "key schools" is a challenge to the fairness of education. "Key schools" enjoy the special education policies of the state or local governments, and enjoy the privileges of national or local priorities. In human capital investment, "key schools" such as "project 211" and "project 985" can receive a large amount of financial allocation and research projects in our country. They can choose the source of students; enjoy high quality resource allocation, teachers and so on. These resources are beyond the reach of ordinary schools. The difference between schools is similar to the "Matthew effect" in human capital allocation, and the rich get richer, the poor get poorer.

\section{E. Cost accounting level}

At present, our school mainly adopts the education financial accounting model, which focuses on the school as a whole. Whatever these resources are consumed, it only accounts for all of the resource value loss incurred during the completion of the education responsibilities given by the government. Simple accounting expenses, while ignoring economic benefit assessment, there is no standard education cost accounting method. Although the school implements the budget management mode of "checking the balance of payments, quotas or orienting, overspending, saving and retention". However, the education cost accounting is not implemented because it is still limited to the stage of calculating the budget surplus. This leads to the cost of education in school has been in the state of "early report budget, year-end report, expenditure on appropriation, insufficient funds, economic benefit no one" and a great waste of school people, money and things.

\section{F. Tuition payment level}

There are three main methods of international tuition fees: real-time tuition system, prepaid tuition system and deferred payment system. Real-time tuition system is the form of compensation for students who pay their tuition fees at the beginning of each semester. Prepaid tuition means that students pay full tuition or reserve for their children before they accept education. Deferred payment means the student will pay the current tuition fee in the form of future income or service. The major forms include student loans, graduate taxes, scholarships and so on[5]. At present, our country adopts mainly real-time tuition system, which gives parents less flexibility. The student will have to pay tuition at the beginning of the semester, otherwise, the students can't afford to study or owe the tuition fees, which will affect the normal development of education activities.

\section{G. Social donation level}

In recent years, our country has increased the total fund of education; however, the social donation has not grown in proportion. Look at the developed countries in the world, social 
donations account for a significant proportion of education inputs. American colleges and universities, especially some elite schools, have established endowments. The United Kingdom investment in education has accounted for about 7 per cent of education funding. Private donations from public schools in Japan, which accounts for $15 \%$ of total school revenue. Although China has established the social endowment administration and the education foundation, the social donation of education funds in China has entered a new stage of development. But compared with developed countries, there is still a huge gap between the size, number, form, scope and recognition of college endowments.

\section{ThE STRATEgy ORIENTATION OF HUMAN CAPITAL INVESTMENT COST-SHARING MECHANISM OPTIMIZATION}

The implementation of the cost-sharing policy of human capital investment has positive meaning and negative significance to education. Therefore, we should take some measures to reduce its negative impact on education equity, so as to better promote the development of education in China.

\section{A. Formulate a "progressive increasing" system}

The "progressive increasing" tuition system is to link the pay level to the level of family income, fully considering residents' ability to pay for tuition. China should divide the families of the whole country into low-income families, middle and low income families, middle and high income families and high-income families according to different criteria. Under the "progressive increasing" tuition system, tuition is positively correlated with household income, that is, high earners pay more, while low-income people pay less. By adopting this costsharing approach, governments can not only reduce investment spending on human resources but also prevent rising tuition fees.

\section{B. Improve the student funding system}

Reform and improvement of the system of student financing, first of all, the loan system should be improved as soon as possible. Since the active commercial of bank in China is mainly operating student loan according to market mode, its profit principle is not conducive to helping the poor students. The state should strengthen its intervention in student loans and establish policy-based financial intermediaries and establish national student loan fund, weaken loan risk. It provides a strong institutional support for the recovery of student loans. This will ensure that low-income students are able to borrow money. Secondly, improve the financial aid and scholarship system. We will clearly stipulate the proportion of financial aid to schools and the amount of special funds earmarked for financial aid to schools, and implements them. Finally, improve the work-study system. The school and society should establish and perfect stable work-study system effectively to ensure students who are in difficulty in family life will be able to increase their paying ability through hard work.

\section{Poverty support}

Poor areas are usually areas where living standards and education levels are weak. Because of the poor economy, they have lost the opportunity to share good basic education and receive education capital investment[6]. Therefore, the state should give full play to the role of macro-control; establish effective compensation mechanism and perfect science education financial transfer payment system and other effective ways of supporting the disadvantaged. For the disadvantaged groups to give a certain tilt to the policy, increase the number of education investment in the weak areas, and increase funding for vulnerable people and support the backward areas in education.

\section{Develop social forces to run schools}

Encouraging social forces to run schools is an important way to alleviate the shortage of education and reduce the burden of national and individual costs. Vigorously develop the social forces to run schools and encourage the establishment and expansion of private colleges and universities to widen the channels for investment in education. Make education cost share diversification, absorb more capital. This will allow the country to scale back its investment to ensure investment priorities. Provide more education resources for low-income people, so that they can enjoy more scholarships, grants and so on, so as to ensure that they are not rejected from the school gate because of poverty. At the same time, vigorously develop social programs, and improve the cost yield of education investment can also by enhancing the teaching reform of public school.

\section{E. Widen the channel of education}

At present, social donation has become an important supplement to the investment and construction and development of human resources in our province. On the one hand, the school itself should take positive action, strengthen management, expand publicity, take the initiative, strive for more social donation. On the other hand, the government should actively establish a scientific and normative management system, improve the relevant laws and regulations and the tax system, and promote the benign development of social donation management. In a word, the theory and practice of actively discussing and studying social donation are of farreaching significance to the diversification and marketization of the source channel of human resources in our province.

\section{F. Establish a cost accounting system}

The old human capital investment accounting system, which only accounts for expenses, ignores the economic benefit assessment and excludes the education cost accounting. For the education funds allocated to the state, the school simply calculates the per capita expenditure, as the data for the application of the budget to the state. The school has long been in the state of economic benefit unattended, resulting in a great waste of people, money and things. Despite the national fiscal reform, the budget management model has been implemented, but it is still limited to the calculation of the budget surplus and the education cost accounting. "The stagnation of education cost accounting and the resulting maladies restrict the development of education. The limited education funds in colleges and universities are not properly utilized, resulting in a serious waste of education resources. This is not compatible 
with optimizing resource allocation and developing education with Chinese characteristics. Therefore, we must reform the existing accounting mode of the school and establish the education cost accounting system.

\section{G. Exerting the role of national finance}

Human resources, as quasi-public products, cannot be made into industries. Even if cost sharing is carried out, government finance should play a leading role in education investment, guaranteeing the higher education funds. In accordance with the law, our country should strengthen the government's investment in education and guarantee the government's main channel role in the investment of education in a certain period of time. Governments at all levels need to shift their view of education investment as a purely consumer investment. Human capital investment should be put in the same important position as infrastructure construction, and as an important fundamental and productive investment. Implementation of education input in accordance with the law, and the "three growth" of education funding under the education law. The education budget should be arranged in strict accordance with the laws and regulations. Make sure that education investment accounts for at least 4\% of GDP, and education accounts for about 1\% of GDP. Ensure that the increase in education allocations in the budget is higher than the growth of fiscal recurring revenue.

\section{H. Improve integrative system of the industry-university- research}

In order to realize the integration construction of university industry and research. The school has the choice and focus on the cooperation with the relevant high-tech enterprises, according to its own disciplinary characteristics. Firstly, by improving its own operational capability, it can tap its own intellectual resources. Drawing on the model of enterprise operation, the capital of the school is expanded into the valueadded capital of the currency, and actively taking the integration path of industry-university-research. Secondly, through the advantages of human capital and enterprise cooperation or self-run enterprises, the education funding source is diversified. Finally, the government should provide more policy support for the special industry of education. For kinds of vocational schools serve in different fields, including the technology transfer, technical training, technical consultation, technical service, technical contract and other technical services income of various industries, the enterprise income tax shall be exempted temporarily.

\section{CONCLUSION}

The pursuit of education justice is the fundamental trend of education development in human society. It is the basic starting point for the reform and development of education worldwide. Therefore, the impact of human capital investment cost sharing has been paid attention to on the fairness of education. Making the cost of education a fair share is only a theoretical ideal, which is hard to do in reality. What we can do is that improve the education opportunity inequality caused by the imperfect human capital investment cost-sharing mechanism, which is the national, individual, family, school and society. Making a scientific human capital investment cost-sharing system to realize the fairness and impartiality of education investment. Promote the harmonious development of society and realize balanced development of interests in all aspects.

\section{REFERENCES}

[1] Levin, Henry, Firiancing Universities in Developing Countries[M]. Forword The Famler Press, 1995.

[2] S.L. Liu, Analysis of spillover effects of human capital[J]. Economic Science, 2014 (2) :79 -90.

[3] M. Li, Study on the cost-sharing of education of family preschool in China[J]. Journal of Educational Science of Hunan Normal University, 2014, (6).

[4] Z.H. Yang, Area of higher education in our country is different from the other [J]. Journal of Higher Education, 2014, (12)

[5] C.S. Yang, Research on the impact of human capital investment on the income gap of urban residents is based on education and health perspectives [D]. Beijing: Beijing Jiaotong University, 2014.

[6] X.P. Jiang, X.H. Hou, The higher education equity research in social transition period [J]. Theoretical Perspective, 2015. 